\author{
Asian Journal of Economic Modelling \\ $\operatorname{ISSN}(e): \quad 2312-3656$ \\ $\operatorname{ISSN}(p): \quad 2313-2884$ \\ DOI: $10.18488 /$ journal.8.2014.24.169.177 \\ Vol. 2, No. 4, 169-177 \\ (C) 2014. AESS Publications. All Rights Reserved. \\ URL: www.aessweb.com
}

\title{
OIL PRICES FLUCTUATIONS \& ITS IMPACT ON RUSSIAN'S ECONOMY; AN EXCHANGE RATE EXPOSURE
}

\author{
Khuram Shafi ${ }^{1+}$ \\ Liu, Hua ${ }^{2}$
}

\author{
'PhD Scholar, School of Management, Hua Zhong University of Science and \\ Technology, Wuhan, China. \\ 'Professor, School of Management, Hua Zhong University of Science and \\ Technology, Wuhan, China
}

(+) Corresponding author

\begin{abstract}
Countries suffering from a shortage of oil reserves or importing oil are trying to reduce the oil consumption. But this can be only possible if alternatives of oil reserves are available. The factors affecting exchange rate are inflation, interest rate, foreign direct investment, government consumption expenditure and balance of trade. This paper seeks to identify the impact of oil prices and risk exposure of exchange rate volatility on economic growth in Russian economy on annual data of from year 1971 to 2012. Based on results it is estimated that imports, exports, inflation, interest rate, government consumption expenditure and foreign direct investment has a significant impact on real effective exchange rate in the long run and short run. Secondly, Engle Granger results indicate that relationship is significant in the long run and its error correction adjustment mechanism in short runs is significant and correctly signed for Russia.
\end{abstract}

Keywords

Oil prices

Russian's economic growth

Co-integration.

Contribution/ Originality: This study is one of very few studies which have investigated literature and empirical finding on Russia (Oil exporting country) in two directions; first it will establish a relationship between oil prices and exchange rate with economic growth, and secondly, measures a long run relationship and short run adjustment mechanism in between macroeconomic variables and exchange rate.

\section{INTRODUCTION}

Oil prices are always debatable and remain vital up-and-down in determining the economic activity of a country. It was already projected and estimated globally that the oil demand is expected to increase ninety eight million barrels/ day in next year (2015) and 118 million barrels per day during next twenty years (in 2030). The rise in oil prices increases inflation in domestic country and transfers income from oil importing to exporting countries. In oil exporting countries the rise in oil prices as considered as a good sign increases earnings from exports. Economic theories indicate that depreciation of exchange rate tends to expand exports and reduce 
imports, while the appreciation of exchange rate would discourage exports and encourage imports. Thus, exchange rate depreciation leads to income transfer from importing countries to exporting countries through a shift in the terms of trade, and this affects the economic growth of both importing and exporting nations. Gross domestic product is one of the important barometers to measure the economic growth. Exchange rate volatility and fluctuation in oil prices adversely affects economic growth. Various factors affecting exchange rate are inflation, interest rate, exports, imports, foreign debt, industrial growth and foreign direct investment. Exchange rate and oil prices have a significant impact on the growth of the economy. So, the research problem is to find out "the macroeconomic variables like imports, exports, inflation, interest rate, government consumption expenditure and foreign direct investment have a significant impact on exchange rate and is exchange rate volatility and oil prices shocks has a significant long run relationship with economic growth and what is its short run adjustment mechanism in short run in Russia." The aim of this paper is; to check the long run as well as short run impact of exchange rate and oil prices on economic growth, to identification of growth rate variables that are affected by exchange rate are inflation, export, import, interest rate, foreign direct investment, government consumption expenditure. This paper extend literature in two directions; first it will establish a relationship between oil prices and exchange rate with economic growth, and measures a long run relationship and short run adjustment mechanism in between macroeconomic variables and exchange rate like exports, imports, interest rate, inflation, foreign direct investment and government consumption.

\section{THEORATICAL BACKGROUND}

\subsection{Impact of Oil Prices on Economic Growth}

Oil price ebb and flow has foremost consequence on economic growth. These consequences are projected to be diverse in oil importing and in oil exporting countries. Raise in oil price is considered excellent news for oil exporting countries and bad news in oil importing countries, the overturn should be expected when the oil price decreases, accordingly, an increase of crude oil price will affect positively the real gross domestic product (GDP). Crude oil is a basic input to production, the theory usually forecast that supply side consequences of oil price while addition, aggregate demand is expected to fall in oil importing countries, and go up in oil exporting countries. Economists are trying to investigate the relationship between oil prices volatility and economic growth and noted that increase in oil prices is regarded as a positive signal for the oil exporting countries and positive reception in exchange rate will have a important positive impact on economic growth. So, for those countries oil prices and appreciation in exchange rate are positively correlated with gross domestic product. The rise in oil prices is due to increase in demand not by supply side effects. Oil prices are more worthwhile than monetary contraction. Increase in oil prices is affecting the oil producing countries in two contexts. First is positive effect that is income and wealth increases in oil producing countries, because importing countries pays more and if the exporting countries utilize income in home country then investment will be more in countries and increase employment in the society. It increase money supply in the society and currency appreciates in this regard. Second effect is negative because increase in oil prices 
will decrease demand for oil in oil importing countries and worsens balance of trade position in oil exporting country (Amano and Van Norden, 1998; Brahim Fezzani, 2011), (Aliyu, 2009), (AlEzzee, 2011), (Bjørnland, 2009), (Kilian, 2007), (Hamilton, 2009), (Jiménez-Rodríguez and Sanchez, 2005).

\subsection{The Impact of Exchange Rate on Economic Growth}

The real exchange rate is a relative price of two currencies domestic and foreign currency. Basically, the real exchange rate can be defined as the nominal exchange rate that takes the inflation differentials among the countries into account. It is used as an indicator of competitiveness in the foreign trade of a country. Any changes in the real exchange rates would lead to fluctuations in short term capital flows. It plays an important role in economic activities; therefore the real exchange rate has been one of the most debated issues both in theory and the practice. The effect of real exchange rate on economic growth has been examined, and found that negative relationship between the two variables. Devaluation of a currency leads contraction in aggregate demand and output. Devaluation increases general price level and decrease in real money value increase demand for nominal money and interest rate and have a negative impact on investment and consumption decisions. Government has to pay more money for external debt which is either generated from taxes or by reducing expenditure. If it is by increase in taxes then it will lessened the private sector spending and negatively affects economy (Munir and Choudhary, 2006). Literature empirically proves that depreciation in exchange rate will make imports expensive that will encourage exports and stronger balance of trade position and leads to higher economic growth. Despite that, appreciation in exchange rate will make imports cheap and has studied affect the economic growth as well (Aliyu, 2009), (Tille, 2003), (Hsing, 2005), (AlEzzee, 2011).

\subsection{The Impact of Macroeconomic Variables on Exchange Rate}

Higher interest rate leads appreciation of the currency and the relationship between exchange rate and interest rate must be treated differently because it is more favorable for traded goods. If government increases its spending that will increases consumption decreases balance of trade and depreciation in exchange rate and have a positive impact on Gross domestic product (Kim, 2007). Foreign direct investment is regarded as an important source of capital financing (Globerman and Shapiro, 1999). Government implement different strategies to foster economic growth and regime stability lead to increase in foreign direct investment inward (Ravn, 2012) has suggested that. If foreign direct investment is used in non-tradable sector then it will leads to appreciation of the currency (Hafeez-ur-Rehman and Imtiaz, 2010). Different countries have proposed different causes of inflation. Either it is due to the supply of money or due to increase in import prices that causes depreciation of the currency (Ali, 1999). Empirical analysis of exchange rate volatility and oil prices fluctuations on economic growth in three courtiers Russia (oil exporting country) Japan (oil importing countries) and china (not both). From the results of Granger causality oil prices cause economic growth and exchange rates cause GDP in Japan and Russia. A rise in oil prices in Russia has a positive impact on economic growth and appreciation in 
rubble will lead increase in GDP in long run and no impact in short run. Japan is unable to produce oil for its domestic consumption rely for oil on other countries has a negative relationship between oil and GDP, appreciation in Japanese yen is associated to fall in GDP in long run as well as in short run. No long run relationship is found in china because it may be oil importing and exporting country and pegging of Yuan with US dollar virtually. The second largest oil producer in the world has increased its economic growth from last ten years. GDP of Russia is increasing due to high oil production and relatively high oil prices, producing 10 million barrel oil per day and exports 7.3 million barrel oil per day. Russian currency rubble is linked with dollar and euro. Appreciation of Russian rubble is positively correlated with economic growth in long run and has no significant impact in short run. Empirical analysis of exchange rate volatility and oil prices fluctuations on economic growth in three courtiers Russia(oil exporting country) Japan(oil importing countries) and china(not both).From the results of Granger causality oil prices cause economic growth and exchange rates cause GDP in Japan and Russi. A rise in oil prices in Russia has a positive impact on economic growth and appreciation in rubble will lead increase in GDP in long run and no impact in short run. Japan is unable to produce oil for its domestic consumption rely for oil on other countries has a negative relationship between oil and GDP, appreciation in Japanese yen is associated to fall in GDP in long run as well as in short run. No long run relationship is found in china because it may be oil importing and exporting country and pegging of Yuan with US dollar virtually. Russia, the second largest oil producer in the world has increased its economic growth from last ten years. GDP of Russia is increasing due to high oil production and relatively high oil prices, producing 10 million barrel oil per day and exports 7.3 million barrel oil per day. Russian currency rubble is linked with dollar and euro. Appreciation of Russian rubble is positively correlated with economic growth in long run and has no significant impact in short run. Demand for oil is increasing day by day and depends upon demand and supply of oil, its consumption and alternatives availability of resources. It is analyzed that increase in oil prices is negatively correlated with economic growth for oil importing country (Jin, 2008).

\section{RESEARCH METHODOLOGY}

Growth of any country is affected by different macroeconomic variables like government investment and consumption decisions, foreign direct investment, political conditions, industrial and manufacturing growth rate, oil prices and exchange rate. Oil prices and exchange rate affect positively as well as negatively to the different countries. Annual data of variable is taken from International Financial Statistics (IFS) from 1971 to 2012. Gross domestic product is taken in national currency in billions. Data of exchange rate variability is taken as CPI based real effective exchange rate from the same source. Data of world oil prices is taken in current US \$.Then conversion of all the data in US dollar for the Russia. Following models are adopted.

$$
\mathrm{GDP}=\alpha+\beta_{1} \Delta \mathrm{ROIL}+\beta_{2} \mathrm{REXR}+\mu
$$

Based on the model of Jin (2008) and Aliyu (2009) co integration technique is applied for the analysis. REXR is real effective exchange rate which is also checked as an endogenous variable with certain macroeconomic variables. Exchange rate of a country is affected by inflation. Annual 
data of imports, exports and government consumption expenditure is taken in local currency in billions. Data of foreign direct investment and Consumer price index (2005) is taken from International financial statistics (IFS) in rate. First of all impact of inflation, interest rate, government consumption expenditure, imports and exports of a country on exchange rate is to be seen by using cointegration technique. So, this is econometric model

$$
\operatorname{REXR}=\beta_{0}+\beta_{1} \mathrm{EXP}+\beta_{2} \mathrm{IMP}+\beta_{3} \mathrm{IR}+\beta_{4} \mathrm{FDI}+\beta_{5} \mathrm{GC}+\mu
$$

Time series modeling and forecasting became quite popular following the publication of the text time series analysis forecasting and control by George box and Gwilym Jenkins in 1976. They suggested some properties of time series that would suggest departures from stationary, that is, these would suggest non stationary. The two main properties were visual cues. First, if a series does not seem to have a constant mean (part of the definition of stationary) when graphed, that is a visible symptom of non-stationary. The stationary or otherwise of a series can strongly influence its behavior and properties -e.g. persistence of shocks will be infinite for non-stationary series. If the variables in the regression model are not stationary, then it can be proved that the standard assumptions for asymptotic analysis will not valid. In other words, the usual "t ratios" will not follow a t-distribution, so we cannot validly undertake hypothesis tests about the regression parameters. If a non-stationary series, yt must be differenced d times before it becomes stationary, then it is said to be integrated of order $d$. We write $y t \sim I(d)$. So if $y t \sim I(d)$ then $\Delta$ dyt $\sim \mathrm{I}(0)$.

An I (1) series contains one unit root,

e.g. $\mathrm{yt}=\mathrm{yt}-1+\mathrm{ut}$

A series is said to be trend stationary when it is stationary around a trend:

$\mathrm{y}_{\mathrm{t}}=\beta_{0}+\beta_{1 \mathrm{t}}+\mathrm{u}_{\mathrm{t}}$

$\mathrm{t}=$ trend

If all variables are found to be integrated of the same order, the following process is generally employed. The first step is to estimate whether stable long-run dependencies exist among the variables, i.e. whether the variables are cointegrated. If the cointegrating relations are identified, the next step is to determine the number of long-run equilibrium relationships or cointegrating vectors among the variables. The two most widely used tests for cointegration are the two-step estimator and the Johansen and Juselius (1990) maximum likelihood estimator. Since the long-run cointegrating relation is found among the variables, the estimation of cointegrating vectors is executed at the same time. If there is evidence of cointegration between two or more variables, then a valid error correction model should also exist between the two variables. The error correction model is then a representation of the short-run dynamic relationship between $\mathrm{X}$ and $\mathrm{Y}$, in which the error correction term incorporates the long-run information about $\mathrm{X}$ and $\mathrm{Y}$ into our model. This implies that the error correction term will be significant, if cointegration exists. In the previous section the cointegrating relationships of the variables are identified, and it will be included explicitly as error-correction terms into a short-run system. The estimated bi-variate ECM for Italy takes the following form:

$$
\begin{gathered}
\Delta \text { RGDPit }=\alpha+\Sigma \beta 1 \text { i } \Delta \text { ROILPit-1 }+\sum \beta 2 \text { i } \Delta \text { REXRit-1 }+\varphi \text { ECTit-1 }+ \text { u } 1 \text { it } \\
(\mathrm{i}=1 \ldots \mathrm{n} 1)(\mathrm{i}=1 \ldots \mathrm{n} 2)
\end{gathered}
$$


Where $\Delta$ is the difference operator, $\mathrm{RGDP}_{t}, \mathrm{ROILP}_{\mathrm{t}}$ and $\mathrm{REXR}_{\mathrm{t}}$ are as defined before; $\mathrm{ECT}_{\mathrm{it}}$ ${ }_{1}$ is the error correction term derived from the long- run co integrating relationship, $u 1 t$ is the white noise error terms $t$ denotes the years and $n 1$ is the lag orders of $\alpha$ 's and $\beta$ 's respectively. The error correction model (ECM) results distinguish between short-run and long-run Granger causality. The above said methodology is also applied on the second model.

\section{RESULTS}

To check cointegration among oil prices, real effective exchange rate with gross domestic product, firstly augmented dickey-fuller (ADF) test is applied. Result shows that there exists a long run relationship among the variables at the first difference as shown in table 1.

Table-1. ADF Test

\begin{tabular}{l|l|l|l|l|l}
\hline Variables & Test Specification & ADF Test & Critical Value & Prb & DW \\
\hline GDP & IT $-\Delta \Delta-1 \%$ & -5.638 & -4.232 & 0.000 & 2.10 \\
OILP & I $-\Delta-1 \%$ & -6.66 & -3.616 & 0.000 & 1.98 \\
REER & I- $\Delta-5 \%$ & -6.018 & -4.227 & 0.0001 & 2.08 \\
\hline
\end{tabular}

Either to check short run adjustment mechanism error correction mechanism is to be used in table 3. Optimal lag selection is tested and it fulfills all the criteria at lag 1 as shown in the table 2. All the series are found to be integrated at the same order. All the variables are significant at first difference, in such case I (1) exist and equilibrium relationship exists among the variables. The two-step Engle and Granger model suggests that if any set of co integrated time series has an error-correction representation, which reflects the short-run adjustment mechanism.

Table-2. Lag selection

\begin{tabular}{l|l|l|l|l|l|l}
\hline Lag & Log L & LR & FPE & AIC & SC & HQ \\
\hline 0 & -368.9932 & NA & 38676.11 & 19.07657 & 19.20454 & 19.12249 \\
1 & -270.9792 & $175.9225^{*}$ & $403.5483^{*}$ & $14.51176^{*}$ & $15.02362^{*}$ & $14.69541^{*}$ \\
\hline
\end{tabular}

The lag value of the residual term must be negative showing that shocks in the long run having short run adjustment mechanism. ECM is general to specific approach to econometric modeling.

Table-3.Cointegration and Error Correction Mechanism

\begin{tabular}{l|l|l|l|l}
\hline Variables & Coeff. & S.E & t-stat & Prob. \\
\hline $\mathrm{C}$ & 8.4492 & 3.8862 & 2.1741 & 0.0365 \\
\hline $\mathrm{D}(\mathrm{REER})$ & 1.0156 & 0.6068 & 1.6737 & 0.1031 \\
\hline $\mathrm{D}($ OILP) & 0.7639 & 0.2832 & 2.6972 & 0.0107 \\
\hline $\mathrm{UT}(-1)$ & $\mathbf{- 0 . 0 1 1 5}$ & 0.0871 & $\mathbf{- 0 . 1 3 1 5}$ & $\mathbf{0 . 8 9 6 1}$ \\
\hline
\end{tabular}

A fundamental parameter in the estimation of the short-run dynamic model is the coefficient of error-correction term which measures the speed of adjustment of real GDP to its equilibrium level. The results show that the factor of the error-correction terms in the model is statistically 
significant and correctly signed. This confirms that GDP has automatic adjustment mechanism and that the economy responds to deviations from equilibrium in balancing manner for Russia. As far as t-statistics are concerned if t-statistics are statistically significant then the shocks will adjust in that year and the remaining will be carry forward to the next year and if t-statistics are insignificant then the shock will recover in the same year. So the econometric equation will be;

$$
\text { GDP }=8.4492-0.0115 \mathrm{Ut}(-1)+1.0156 \text { REER + 0.7639 OILP }
$$

From the above results, the signs of real effective exchange rate and oil prices both are positive showing that 1 unit increase in exchange rate will cause 1.0156 units change in economic growth and 1 unit increase in oil prices will cause 0.7639 units change in gross domestic product.

To check either cointegration exist in consumer price index ( CPI), export( EXP), government expenditure (GCE), imports (IMP), interest rate (IR), foreign direct investment (FDI) with endogenity of real effective Exchange rate (REER), which shows stochastic trend that can only be removed by taking first difference. Unit root test is applied to check the Stationary of the data at level and first difference. A technique for Stationary of data is Augmented dickey fuller a most trustworthy source.

Table-4. ADF test

\begin{tabular}{l|l|l|l|l|l}
\hline Variable & Test Specificion & ADF Test & Critic-al Value & Prb & DW \\
\hline ER & IT $-\Delta-1 \%$ & -5.589 & -3.621 & 0.0000 & 1.94 \\
CPI & IT $-\Delta-1 \%$ & -4.595 & -4.219 & 0.0038 & 2.13 \\
EXPR & IT $-\Delta-1 \%$ & -9.306 & -4.219 & 0.0000 & 1.84 \\
GCE & IT $-\Delta-10 \%$ & -3.329 & -3.198 & 0.0769 & 2.26 \\
IMP & IT $-\Delta-1 \%$ & -7.709 & -4.219 & 0.0000 & 1.91 \\
IR & IT $-\Delta-1 \%$ & -7.340 & -4.219 & 0.0000 & 1.97 \\
FDI & I- $\Delta-1 \%$ & -6.116 & -4.235 & 0.0001 & 1.80 \\
\hline
\end{tabular}

All the variables are integrated at first difference so order of integration is 1 . After the estimation of order of cointegration, lag order must be selected. As far as to achieve this purpose VAR lag order selection criteria must be used. For this purpose we use: Final Prediction Error (FPE), Akaike Information Criterion (AIC), Schwarz Information Criterion (SIC), and HannanQuinn Information Criterion (HQ).Table 5 Shows the results of the optimal lag Selection. According to the results lag 1 is to be selected for in the VAR model.

Table-5. Optimal Lag selection Criteria

\begin{tabular}{l|l|l|l|l|l|l}
\hline Lag & Log L & LR & FPE & AIC & SC & HQ \\
\hline $\mathrm{O}$ & -858.0943 & NA & $7.08 \mathrm{e}+11$ & 44.31253 & 44.56846 & 44.4043 \\
1 & -599.3784 & $424.5594^{*}$ & $7940796 . *$ & $32.89120^{*}$ & $34.6827^{*}$ & $33.5339^{*}$ \\
\hline
\end{tabular}

The value of Trace statistics and maximum Eigen value will tell the number of cointegration equations in this. It is noted that Trace statistics is greater than critical value at $5 \%$ level of significance then there exist cointegration (long run relationship) among the variables. From the results in the table 6 as per trace statistics there are 6 cointegration equations. 
Table-6. Unrestricted cointegration Rank Test

\begin{tabular}{|c|c|c|c|c|}
\hline No. of CE(s) & Eigenvalue & $\begin{array}{l}\text { Trace } \\
\text { Statistic }\end{array}$ & 0.05 Critical Value & Prob.** \\
\hline None ${ }^{*}$ & 0.999946 & 1091.625 & 125.6154 & 0.0001 \\
\hline At most $1^{*}$ & 0.999898 & 718.3555 & 95.75366 & 0.0001 \\
\hline At most $2 *$ & 0.968145 & 369.2028 & 69.81889 & 0.0001 \\
\hline At most $3 *$ & 0.909406 & 238.2340 & 47.85613 & 0.0001 \\
\hline At most $4^{*}$ & 0.899828 & 146.9819 & 29.79707 & 0.0001 \\
\hline At most $5^{*}$ & 0.734876 & 59.54896 & 15.49471 & 0.0000 \\
\hline At most 6 & 0.352994 & 9.101728 & 10.841466 & 0.126 \\
\hline
\end{tabular}

\section{$\mathrm{REER}=277.16-7.342 \mathrm{expr}+42.52 \mathrm{imp}+2.71 \mathrm{inf}+2.26 \mathrm{IR}+52.877 \mathrm{FDI}+68.867 \mathrm{GCE}$ \\ $\begin{array}{lllll}(1.46) & (2.29) \quad(1.15) & (2.73) & (1.15) \quad(-2.82)\end{array}$}

Equation indicates that in Russia 1 unit increase in exports will cause decrease in real effective exchange rate by 7.342 units and 1 unit increase in imports will cause 42 unit increases in real effective exchange rate and interest rate, foreign direct investment, inflation and government consumption expenditure are positively correlated. So, 1 unit increase in interest rate, foreign direct investment, inflation and government consumption expenditure will cause 2.2, $52.877,2.7$ and 68.8 units increase in real effective exchange rate.

\section{CONCLUSION}

Oil prices and exchange rate has positive relation with economic growth of the Russia. So positive sign showing that rise in oil prices will be affecting positively to gross domestic product and in exchange rate will also increase in gross domestic product. Short run error adjustment mechanism shows that all the errors exist in short run. Secondly, effect of imports, exports, interest rate, inflation, government consumption expenditure and foreign direct investment are having effect on exchange rate. Interest rate, inflation, government consumption and import of the country have significant positively related to the exchange rate while the exports have negatively related to the real effective exchange rate.

\section{REFERENCES}

Al-Ezzee, D.I., 2011. Real influences of real exchange rate and oil price changes on the growth of real GDP: Case of Bahrain. International Conference on Management and Service Science, 8: 155-164.

Ali, E.A.A.S.A., 1999. Relationship between exchange rate and inflation. Pakistan Economic and Social Review, 37(2): 139-154. Available from http://www.jstor.org/stable/25825193.

Aliyu, S.U.R., 2009. Impact of oil price shock and exchange rate volatility on economic growth in Nigeria: An empirical investigation. Research Journal of Internatıonal Studies, (11): 4-15.

Amano, R.A. and S. Van Norden, 1998. Oil prices and the rise and fall of the US real exchange rate. Journal of International Money and Finance, 17(2): 299-316.

Bjørnland, H.C., 2009. Oil price shocks and stock market booms in an oil exporting country. Scottish Journal of Political Economy, 56(2): 232-254.

Brahim Fezzani, D.N., 2011. Oil prices fluctuation impact on Iraq's economy. European Journal of Social Sciences, 26(4): 626-633. Available from http://www.europeanjournalofsocialsciences.com. 
Globerman, S. and D.M. Shapiro, 1999. The impact of government policies on foreign direct investment: The Canadian experience. Journal of International Business Studies, 30(3): 513-532.

Hafeez-ur-Rehman, A.A.J. and A. Imtiaz, 2010. Impact of foreign direct investment (FDI) inflows on equilibrium real exchange rate of Pakistan. A Research Journal of South Asian Studies, 25(1): 125141.

Hamilton, J.D., 2009. Causes and consequences of the oil shock of 2007-08. National Bureau of Economic Research.

Hsing, Y., 2005. Impact of monetary policy, fiscal policy, and currency depreciation on output: The case of Venezuela. Briefing Notes in Economics, (65): 1-9. Available from http://www.richmond.ac.uk/bne.

Jiménez-Rodríguez, R. and M. Sanchez, 2005. Oil price shocks and real GDP growth: Empirical evidence for some OECD countries. Applied Economics, 37(2): 201-228.

Jin, G., 2008. The impact of oil price shock and exchange rate volatility on economic growth: A comparative analysis for Russia Japan and China. Research Journal of Internatıonal Studıes, (8): 98-111.

Johansen, S. and K. Juselius, 1990. Maximum likelihood estimation and inference on cointegration-with applications to the demand for money. Oxford Bulletin of Economics and Statistics, 52(2): 169-2 10.

Kilian, L., 2007. Not all oil prices are alike. Disentangling demand and supply shocks in the oil market forthcoming in American. Economic Review: 1053-1069.

Kim, J., 2007. Real exchange rates and real interest differentials for sectoral data: A dynamic SUR approach. Economic Letters, 97: 247-252. Available from http:/www.elsevier.com/locate/econbase.

Munir, A.S. and M.A.C. Choudhary, 2006. Effects of exchange rate on output and price level: Evidence from Pakistan economy. Lahore Journal of Economics, 12(1): 49-77.

Ravn, M.O.S.-G., Stephanie Uribe, Martín, 2012. Consumption, government spending, and the real exchange rate. Journal of Monetary Economics, 59(3): 215-234. Available from http://www.sciencedirect.com/science/article/pii/S0304393212000219. 10.1016/j.jmoneco.2012.02.001.

Tille, C., 2003. The impact of exchange rate movements on U.S. Foreign debt. Current Issues I Economics and Finance, 9(1): 1-7. Available from www. n e w y orkfed.org/r magh o m e/c u r r_is $\underline{\mathrm{s}}$ 